\title{
Philippe Gugler*
}

\section{RECENT POLICY DEVELOPMENTS REGARDING FOREIGN INVESTMENT}

This contribution identifies the main recent patterns affecting the international investment policy landscape. It reflects the main developments and challenges that call for reforms at national and international levels and comprises three parts. The first part is dedicated to national investment policies promoting or restricting international investments. The second covers the developments occurring at international policy level, new developments regarding international investment agreements (IIAs) and other treaties are discussed. The third part focuses on the three main policy, societal and technological developments influencing the new development of investment policies at national or international levels: Countries'sustainable goals for economic development, the new industrial policy measures applied by some major trading nations and, finally, the predominance of the digital economy, which affects the way firms do business.

\section{Evolución reciente de la política de inversión internacional}

En esta contribución se identifican los patrones que definen el panorama de la política de inversión internacional, abordándose los principales desarrollos y desafios que exigen reformas en el plano nacional e internacional. La primera sección está dedicada a las políticas nacionales de inversión, que promueven o restringen las inversiones internacionales. La segunda cubre el plano de las politicas internacionales, examinándose las principales novedades relativas a acuerdos internacionales de inversión (AII) y otros tratados. La tercera parte se centra en el ámbito normativo, social y tecnológico, dada su influencia en el nuevo desarrollo de las políticas de inversión, a nivel nacional o internacional: los objetivos de desarrollo sostenible para los países, las nuevas medidas de política industrial aplicadas por algunas de las principales economías comerciales y, por último, el predominio de la economía digital, que afecta a la forma en que las empresas hacen negocios internacionales.

Keywords: investment policy, multinational enterprises from emerging countries, digital economy. Palabras clave: política de inversión, multinacionales de países emergentes, economía digital. JEL: F13, F21, F23.

\footnotetext{
* Director of the Center for Competitiveness at the University of FribourgSwitzerland. President of the Department of Economics from the Faculty of Economics and Social Sciences at the University of Fribourg.

Final version: May 2019.

DOI: https://doi.org/10.32796/ice.2019.909.6892
} 


\section{Introduction}

Since the first companies' internationalization operations took place, governments have taken action to influence inward and outward investments (Dunning and Lundan, 2008, p. 663; Van Assche, 2018, p. 117; Rodrik, 1995). The motivations have been diverse: The main issues addressed have been, inter alia, the level of investment, the type of investment, the modes of entry and the impact and behavior of multinational enterprises (MNEs). As underlined by Dunning and Lundan, the interactions between governments and MNEs have evolved over time due to the changing patterns of the international economy, governments' economic development goals, and the emergence of new investors (Dunning and Lundan, 2008, p. 663). Indeed, emerging economies' foreign direct investments (FDI) have increased dramatically over the last two decades, with these trends reinforced by the importance of family firms, state-owned enterprises (SOEs), and sovereign wealth funds (SWFs) investing abroad (Eden, 2016, p. 4). The policy patterns affecting FDI are at work at an individual country level as well as internationally. As noted by Sauvant: "The growth of FDI, an integrated international production system, and the global value chains associated with it was possible because of an enabling policy framework, both at the national and international levels" (Sauvant, 2016, p. 1).

\section{National investment policies}

The main developments of national investment policies address inward FDI. In general, policies regarding outward FDI aim to help and support domestic firms to invest abroad: "These measures are typically intended to advance a home country's strategic economic interests and, in particular, enhance the international competitiveness of its firms by helping them establish a portfolio of locational assets" (Sauvant, 2016, pp. 7-8). The spectrum of these measures is broad, ranging from simple advice to financial assistance. Some measures may be, among others, sector specific and/or modes of entry specific and may target specific types of investors, such as SMEs. With regard to the national policies affecting inward FDI, the main measures are the liberalization and promotion of FDI, on the one hand, and investment screening and investment restrictions, on the other (Eden, 2016; Sauvant and Hamdani, 2015; UNCTAD, 2018). This contribution focuses on policies impacting inward FDI.

\section{Liberalization or promotion measures}

The vast majority of all new investment policies adopted over recent decades are based on promotion and facilitation measures regarding inward FDI (UNCTAD, 2017, p. 100). This approach reflects the goal of all countries to attract investments that positively impact their economic development (Alfaro, 2016). In that respect, investment promotion policies and actions have gained importance in recent years (Sauvant, 2016, p. 2). Stronger competition among investment promotion agencies (IPAs) to attract foreign investors, in general, and technology-driven activities, in particular, is observed nationally and regionally (lammarino, 2018, p. 158). Sauvant identified several generations of investment promotion regimes (Sauvant, 2016, p. 2): The first generation comprises measures opening countries to FDI, the second generation reflects active promotion actions informing and prospecting potential foreign investors, and, in a third generation, IPAs have deployed their efforts to target foreign investors according to their economic and technological development priorities. These kinds of policies may have the benefit of selecting appropriate investments according to the specific features of the host country but may also present the drawback of incorrect sectors being targeted (Sauvant, 2016, p. 2). The fourth generation of investment promotion not only considers inward FDI tools to contribute to economic development and competitiveness, but increasingly focuses on so-called "sustainable FDI". 
According to UNCTAD, the main liberalization (partial or full) observed over the last few years has occurred in specific industries such as manufacturing, transport and energy (UNCTAD, 2018, p. 80). The main measures comprise, inter alia, the reduction of entry barriers (e.g. the opening of formerly closed sectors to foreign investors); the privatization measures that benefit domestic as well as foreign investors; the facilitation of foreign investors' operations; the simplification of administrative procedures; the granting of investment incentives (fiscal incentives, financial incentives); the creation of "special economic zones" (SEZs) and the reform of domestic investment dispute mechanisms (Sauvant, 2016, p. 2; UNCTAD, 2018, pp. 82-83).

\section{Restrictive measures}

Although the majority of investment measures implemented over the last few years are liberalization or promotion policies, the share of regulatory or restrictive investment measures has increased in recent years (UNCTAD, 2017, p. 99; UNCTAD, 2018, p. 80). Recognizing that most countries are keen to attract FDI, Sauvant indicates that: "In recent years, however, national policies toward FDI have become more nuanced, reflected in the increasing share of national policy measures that make the investment climate less welcoming" (Sauvant, 2016, p. 2). Developed countries, usually the home of outward FDI, have been recipients of inward FDI from emerging countries, creating a new phenomenon in the worldwide distribution of FDI (Buckley, 2017; Tavares and Lehmann, 2017). A wave of mergers and acquisitions (M\&A) from emerging country MNEs, such as Chinese firms in United States and Europe, has raised some national security concerns with regard to, among others, strategic industries and strategic domestic assets, such as key infrastructure (Wehrlé and Pohl, 2016, p. 8). The increasing involvement of SOEs as foreign investors has created concerns in developed countries (Cuervo-Cazurra, 2018). The OECD Guidelines for Recipient Country
Investment Policies Relating to National Security were adopted in 2009 (OECD, 2009); the guidelines provide recommendations on how to address national security issues in the regulation of investment. Since their adoption, these guidelines have been used by several countries in reforming their regulatory framework for this matter. Recently, the trade-offs between promoting inward investment, on the one hand, and addressing national security concerns, on the other, have been challenging in several countries (Wehrlé and Pohl, 2016, p. 10). Recently, some M\&A have been impeded for several reasons, such as national security, or for prudential or competition policy reasons (UNCTAD, 2018, p. 86). For example, Italy has implemented new measures to forbid M\&A in some high-tech industries, implicating non-EU firms in cases of threats affecting the national interest and national security (UNCTAD, 2018, p. 84). According to UNCTAD, in 2017 the main M\&A that were forbidden by governments were in financial services, digital services and several high-tech sectors, such as ICTs (UNCTAD, 2018, p. 86).

\section{Investment screening mechanisms}

We can observe a recent move toward the introduction of new or modified screening mechanisms of foreign investments (UNCTAD, 2018). Several reasons may explain this trend, such as the adoption of protectionist measures affecting trade by some countries whose effects have spread in the landscape of foreign investment. Another reason is greater suspicion regarding the real goals of some MNEs, particularly the SOEs and SWFs. The main recent developments have occurred in the European Union (EU), as well as in the United States.

In September 2017, the European Commission proposed a new screening framework. According to the European Commission: "(...) in some cases foreign investors might seek to acquire strategic assets that allow them to control or influence European enterprises, the activities of which are critical for the security and 
public order in the EU and in its Member States" (European Commission, 2018). A political agreement among EU institutions on this framework for screening FDI was reached in November 2018. In the United States, in August 2018, the President signed the Foreign Investment Risk Review Modernization Act (FIRRMA). This act extends the scope of operations to be scrutinized by the Committee on Foreign Investment in the United States (CFIUS) in case of suspicion that national security may be threatened (UNCTAD, 2018, p. 84). The act contains provisions that may significantly restrict inward FDI from specific countries in some US sectors, opening the door to unwelcome decisions based on certain political orientations. As noted by Moran: "Such a move opens the door to a political process for which there is no logical end in sight" (Moran, 2018, p. 2).

Because numerous countries, including the largest economies, have unilaterally implemented new measures or modified their practices regarding the screening of foreign investments, efforts to harmonize the foreign investment landscape are strongly challenged, and these developments may create unwelcome domino effects. Therefore, there are calls to urge governments to harmonize their procedures and criteria on the screening of FDI (Pohl, 2019, p. 2).

\section{International investment policies}

\section{The modernized landscape of IIAs}

The development of international investment policies is closely related to the evolution of measures affecting investments at the national level (Sauvant, 2016, p. 9). Indeed, as indicated by UNCTAD: "Investment laws and IIAs are separate but closely related policy tools for dealing with foreign investment. In each, policymakers need to decide how to treat foreign investment, how to balance investor rights and obligations, how to incorporate sustainable development considerations and how to deal with the interaction between the two instruments. On all these issues, investment laws and IIAs can be a mutual source of inspiration, as IIA negotiators may learn from policy approaches taken in investment laws and vice versa" (UNCTAD, 2017, p. 110).

UNCTAD identified 3,322 IIAs by the end of 2017, comprising 2,946 bilateral investment treaties (BITs) and nine treaties comprising investment provisions (TIPs) (UNCTAD, 2018, p. 88). By the end of 2017, there were 855 investor-state dispute settlements (ISDS) (UNCTAD, 2018, p. 88), and existing "old generation treaties" have also been modernized (UNCTAD, 2018 , p. 98). The main recent evolution of the international landscape governing FDI reflects either the adoption of new models of agreements or the modernizing process of existing "old-generation" agreements (UNCTAD, 2017, p. 126). These new IIAs are mostly based on the so-called "UNCTAD Road Map for IIA Reform" (UNCTAD, 2015; UNCTAD, 2016). This road map comprises five domains: "Safeguarding the right to regulate, while providing protection"; "reforming investment dispute settlement"; "promoting and facilitating investment"; "ensuring responsible investment"; and "enhancing systemic consistence" (UNCTAD, 2017, p. 117).

As highlighted by Sauvant: "Any discussion of strengthening the international investment regime needs to begin with the very purpose of the regime. Given the origin of IIAs, it is not surprising that its principal purpose has been, and remains, to protect foreign investors and, more recently, to facilitate the operations of investors, seeking to encourage in this manner additional FDI flows and the benefits associated with them" (Sauvant, 2016a, p. 7). The first treaties comprised provisions regarding, inter alia, nationalization, the repatriation of incomes, fair and nondiscriminatory treatment, most favored nation (MFN) status and provisions on dispute settlements (Sauvant, 2016, p. 10). More recently, the facilitation of investor operations in host countries has gained increased attention in the new and amended international agreements (Sauvant, 2016a, p. 7). As we will discuss below, a new dimension, promoting sustainable FDI, 
is shattering the global arena of international investment agreements: "In particular, IIAs need to recognize, in addition, the need to promote sustainable development and FDI flows that support this objective. Further objectives include the protection of public welfare and human rights, including public health, labour standards, safety, and the environment" (Sauvant, 2016a, p. 7). This new objective regarding sustainable investment implies that IIAs need to allow for enough "space" to regulate (right to regulate). In its 2018 report, UNCTAD observes a significant number of socalled "new generation of IIAs" including sustainable development provisions as well as "preservation of regulatory space" safeguards (UNCTAD, 2018, pp. 9596). However, the recent inclusion of measures for the right to regulate does not imply any reduction of the investment protection measures included in the IIAs (UNCTAD, 2017, p. 119). Nevertheless: "The balance between investor protection and the right to regulate is a central issue in current debates and policies concerning investment treaties" (Gaukrodger, 2016, p. 6).

Among the main open discussions, ISDS issues need to be further developed since they raise concerns regarding, among others, the inconsistency of the interpretation of treaty provisions on ISDSs (Pohl, 2018, p. 7; Gaukrodger, 2017, p. 6; Sauvant, 2016a, pp. 8-9).

\section{Plurilateral developments}

The OECD Code of Liberalisation of Capital Movements, created in 1961, is a legally binding plurilateral instrument on cross-border investments. The provisions of the code focus on openness, transparency and cooperation among adhering countries (OECD, 2018, p. 3). The code is the sole multilateral tool addressing international capital flows apart from the rules adopted by the European Union and the European Economic Area (OECD, 2007, p. 9). As indicated by the OECD: "For more than 50 years, the Code has provided a balanced framework for countries progressively to remove barriers to the movement of capital, while providing flexibility to cope with situations of economic and financial instability (...). Under the Code, an adhering country is entitled to benefit from the liberalisation of other adhering countries regardless of its own degree of openness" (OECD, 2018, p. 4). The provisions of the code foresee a peer review process aimed at increasing transparency and avoiding conflicts as well as "beggar-thy-neighbor" policies (OECD, 2017, p. 11).

Since 2012, the code has been open to non-member OECD countries, and, in 2016, the adhering countries accepted a proposal to review it. The main aim of this proposal was to strengthen the code with regard to transparency and good practices, thus liberalizing and managing cross-border capital flows (OECD, 2018 , p. 4). The code does not replace a multilateral agreement on investment (MAI), as was contemplated by the OECD in 1995. After two years of negotiations, the participating countries failed to reach an agreement, and the project ended in 1998. The oppositions to this agreement were numerous for various reasons, such as the feeling that the agreement would prioritize rich countries, democratic rights and the sovereignty of countries would be weakened, and important issues such as environmental and labor standards would be affected (UNCTAD, 1999, pp. 23-25) 1 .

In parallel to the ongoing efforts to apply and amend, if necessary, the provisions of the code, the OECD started to develop a plurilateral framework on investment (PFI) in 2006 (OECD, 2015, p. 3). The PFI has been updated since its creation. As stated by the OECD: "Beyond macroeconomic stability, political predictability, social cohesion and upholding the rule of law, which are pre-conditions for sustainable development, the Framework considers numerous policy dimensions in an integrated manner, drawing on global good practices including: investment policy; investment promotion and facilitation; trade policy; competition policy; tax policy; public governance; corporate governance; policies for enabling

\footnotetext{
1 GPF (2019).
} 
responsible business conduct; human resources development; an investment framework for green growth; private investment in infrastructure; and financing for investment" (OECD, 2015, p. 12). Some experts are of the view that the opening of the PFI to non-OECD countries could contribute to building the first steps aimed at contemplating - again - a multilateral framework on investment (Sauvant, 2016a, p. 9).

\section{Multilateral developments}

Since the creation of the GATT in 1947, foreign investment has been considered as part of the multilateral rules being developed. Provisions regarding foreign investment have been negotiated within the discussion related to the Havana Charter that never entered into force. The establishment of the WTO in 1995 with new multilateral rules did not anchor a general multilateral agreement on investment. Nevertheless, the General Agreement on Trade in Services (GATS) contains some investment measures as far as mode three (presence abroad) of trade in services is concerned. Some investment provisions are also in force in the Agreement on Trade-Related Investment Measures (TRIMs) as far as trade may be affected (Zang, 2018, p. 2). In 1996, a working group instigated by developed countries was created to contemplate how to insert investment measures within the multilateral framework (Singapore Ministerial Meeting). However, these discussions also failed, mainly due to the opposition of developing countries, and it has been decided since then to exclude investment measures from the current discussion related to the WTO (Joseph, 2018, p. 1).

A past attempt of developed countries to initiate formal negotiations on an investment agreement at the WTO, as part of the Singapore issues, was blocked by developing countries, who argued that investment does not come under the mandate of that organization and that the relationship between trade and investment is unclear. However, in the spring of 2017, some important developing and emerging countries, such as
China, Brazil, and Korea, initiated new momentum regarding the WTO proposition on the Investment Facilitation Agreement (Joseph, 2018, p. 1). As stated by Joseph: "The IFA proposal also reflects a critical shift in the position of developing countries on the relationship between trade and investment and the WTO's adequacy for addressing investment issues" (Joseph, 2018, p. 29).

The OECD and UNCTAD have launched new initiatives regarding investment facilitation. The OECD is currently working to promote progress toward a more efficient international framework facilitating foreign investment (Novik and De Crombrugghe, 2018). As noted by UNCTAD: "Investment facilitation is the set of policies and actions aimed at making it easier for investors to establish and expand their investments, as well as to efficiently conduct their day-to-day business in host countries" (UNCTAD, 2018, p. 157). Table 1 illustrates the OECD approach that favors parallel development at the plurilateral level (short term) as well as at the multilateral level (long term).

According to UNCTAD, the current national and international policies on investment have dedicated relatively modest attention to investment facilitation (UNCTAD, 2016, p. 117), with UNCTAD thus promoting efforts to strengthen investment facilitation within national and international policies on cross-border investments. The scope contemplated by UNCTAD is quite broad: "Investment facilitation covers a wide range of areas, all with the ultimate objective of attracting investment, allowing investment to flow efficiently, and enabling host countries to benefit effectively. Transparency, investor services, simplicity and efficiency of procedures, coordination and cooperation, and capacity building are among the important principles. It interacts at all stages of investment, from the pre-establishment phase (such as facilitating regulatory feasibility studies), through investment installation, to services throughout the lifespan of an investment project" (UNCTAD, 2016, p. 117).

A new initiative aimed at facilitating international investment has been launched recently at the WTO 


\section{TABLE 1}

\section{OECD APPROACH TOWARD POTENTIAL ELEMENTS OF AN INTERNATIONAL FRAMEWORK FOR INVESTMENT FACILITATION}

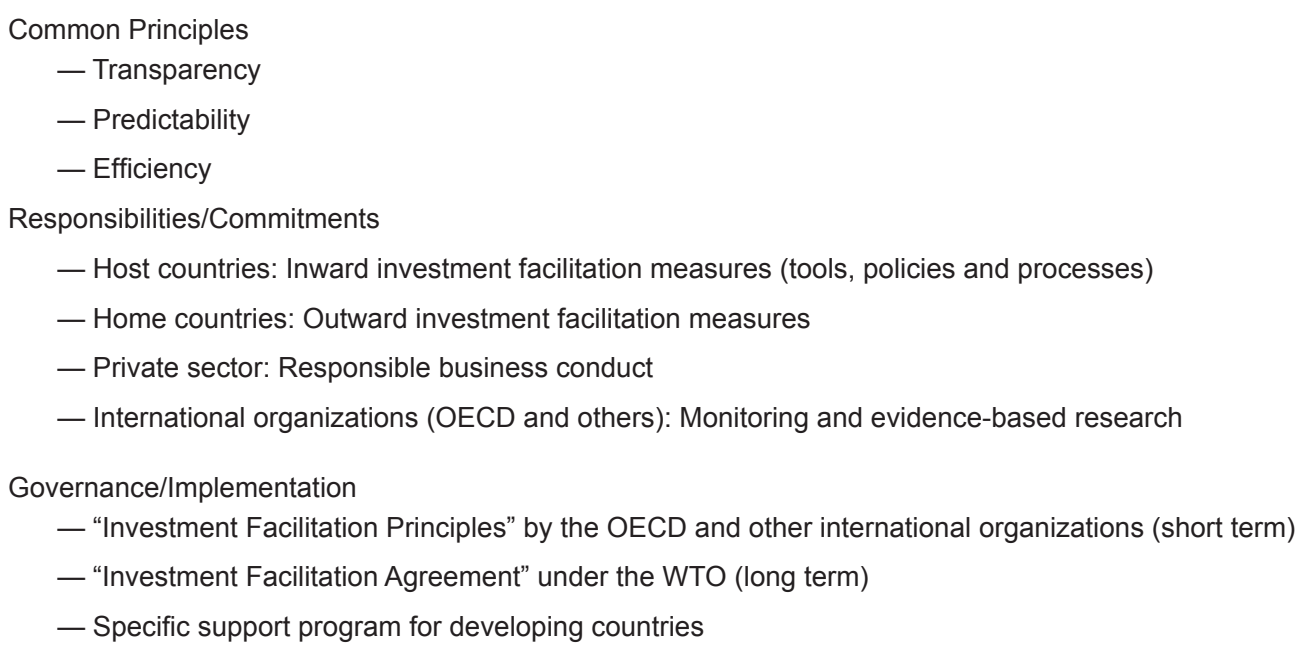

SOURCE: Novik and De Crombrugghe, 2018, p. 10 (reproduction of Box two, p. 10).

(Hamdani, 2018; Hees et al., 2018). This initiative uses the Trade Facilitation Agreement (TFA), entered into force on February 2017, as a model: In April 2017, some WTO member states initiated a dialogue addressing the linkages between trade and investment with the aim of reaching an agreement on investment facilitation in light of the TFA". According to the proponents: "The focus, $(\ldots)$, is not on changing members' investment policies, but on implementing and administering these policies transparently, efficiently and predictably"3. The discussions held so far relate to the improvement of regulatory predictability and transparency, the improvement of administrative procedures, and the enhancement of international cooperation, with special attention to fulfilling the needs of developing countries and other issues that may facilitate international investment. However, the discussions do not address some

2 WTO (2019).

3 WTO (2019). issues, such as market access, investor-state dispute settlement and investment protection ${ }^{4}$.

\section{New features impacting the investment policy landscape}

The recent developments of the national and international investment policy landscape, as well as the ongoing discussion regarding further reforms of agreements, regulations and guidelines impacting foreign investment, have been shaped by several new technological, political and economic trends. Among the numerous factors that may influence the investment policy framework, three deserve special attention: The Sustainable Development Goals committed to by most countries, the new development of industrial policies implemented by major countries, and the fact that the digital economy is anchored in the global economy.

\footnotetext{
4 WTO (2019)
} 
TABLE 2

\section{INTERNATIONAL INVESTMENT POLICY CHALLENGES}

Strengthening the development dimension of IIAs

— "Safeguarding policy space for sustainable development needs.

- Making investment promotion provisions more concrete and consistent with sustainable development objectives".

Balancing the rights and obligations of States and investors

— "Reflecting investor responsibilities in IIAs.

— Learning from and building on corporate social responsibility (CSR) principles".

Managing the systemic complexity of the IIA regime

— "Dealing with gaps, overlaps and inconsistencies in IIA coverage and content and resolving institutional and dispute settlement issues.

— Ensuring effective interaction and coherence with other public policies (e.g. climate change, labour) and systems (e.g. trading, financial)".

SOURCE: Tuerk, E. and Rojid, F. (2012).

\section{FDI policy and sustainable development}

In 2015, the United Nations member states adopted The 2030 Agenda for Sustainable Development (United Nations, 2015). The Agenda comprises 17 Sustainable Development Goals (SDGs) to be applied by developing and developed countries - public as well as private agents - to promote economic growth while improving social progress (UNCTAD, 2014, p. 137). As far as MNEs are concerned, an important issue is how to correctly involve MNEs in the SDGs (Van Zanten and Van Tulder, 2018, p. 209; Sauvant and Mann, 2017, p. 1). National and international investment policies are obviously an important element of all policy actions to be assumed under the umbrella of the SDGs (UNCTAD, 2014 , p. 139; UNCTAD, 2015, p. 6). Regarding national investment policies, investment measures are frequently integrated into national development strategies in addition to other actions to promote social and environmental progress (UNCTAD, 2015, p. 6). At the international level, as noted by UNCTAD: "Most of today's new IIAs include sustainable development-oriented reform elements that preserve the right to regulate, while maintaining investor protection, foster responsible investment and improve investment dispute settlement" (UNCTAD, 2017, p. 117). However, there are still multiple challenges to translating the SDGs into new and older IIAs (Table 2).

UNCTAD launched the Investment Policy Framework for Sustainable Development in Addis Ababa in 2015. This instrument provides guidelines for the adoption of the new generation of investment policies (Table 3) (UNCTAD, 2015).

\section{FDI policy and industrial policy}

As stated by UNCTAD, more than 80 countries representing approximately 90 percent of the world GDP have adopted industrial policy measures over the last five years: "Among industrial policies, about 90 per cent stipulate detailed investment policy tools, mainly fiscal incentives and SEZs, performance requirements, investment promotion and facilitation, and, increasingly, screening mechanisms" (UNCTAD, 2018, pp. 139-140). Countries adopt or modify their industrial policies for multiple reasons, such as preserving and creating jobs; 
TABLE 3

\section{UNCTAD “INVESTMENT POLICY FRAMEWORK FOR SUSTAINABLE DEVELOPMENT”}

"The Investment Policy Framework consists of an overarching set of Core Principles for Investment Policymaking that serve as design criteria for three sets of operational guidelines or action menus:

— Guidelines for national investment policies

— Guidance for the design and use of international investment agreements (IIAs)

- An action menu for the promotion of investment in sectors related to the Sustainable Development Goals"

SOURCE: UNCTAD, 2015a, p. 6 and Investment Policy Hub (2019).

TABLE 4

\section{PERFORMANCE REQUIREMENTS POTENTIALLY CONDITIONED BY IIAS}

— "Local content requirements

— Trade-balancing requirements

- Requirements to establish a joint venture with domestic participation

- Requirements for a minimum level of domestic equity participation

- Requirements to locate headquarters for a specific region

- Employment requirements

- Export requirements

- Restrictions on sale of goods or services in the territory where they are produced or provided

- Requirements to supply goods produced or services provided to a specific region exclusively from a given territory

- Requirements to act as the sole supplier of goods produced or services provided

- Requirements to transfer technology, production processes or other proprietary knowledge

- Research and development requirements"

SOURCE: UNCTAD, 2018, p. 153.

boosting innovation in specific sectors, particularly in the field of the digital economy; promoting specific industries; protecting specific sectors; and improving global value chains (GVCs). Among all the industrial policies, policies regarding FDI have always played an important role among all types of industrial policies and regulations (UNCTAD, 2018, p. 131). The promotion of FDI is one of the core elements for fostering economic development through multiple kinds of spillovers (access to financial resources, skills, knowledge, markets, etc.). Therefore, countries try to attract FDI through different types of incentives (Tavares-Lehmann et al., 2016). In many cases, investment incentives are linked to performance requirements comprising, inter alia, "minimum investment amount", "contribution to R\&D" and "technology transfer", and the "creation of jobs". (Table 4) (Feldman, 2018, p. 1; UNCTAD, 2018, pp. 152-153).

Special economic zones and technological/industrial parks are also developed in light of industrial policies impacting FDI (Wessner, 2009). These zones are created, inter alia, to attract FDI, promote the integration of local firms into GVCs, promote exports and to create 
employment (UNCTAD, 2018, p. 154). As noted by UNCTAD: "These zones usually offer fiscal incentives, infrastructure and services, streamlined business registration and customs procedures, facilitated processing of labour and immigration permits, and other investment facilitation services" (UNCTAD, 2018, p. 154). An increasing number of countries and regions tend to develop zones that specialize in specific activities, industries, or technologies that benefit from economic advantages and strengths (OECD, 2011). As highlighted by UNCTAD: "The contribution of SEZs to industrial development can be significant, especially where they foster the creation of clusters" (UNCTAD, 2018, p. 155). New industrial policies generally comprise investment facilitation measures, which is a domain that has not played an important role in the past and has recently been recognized as an important policy tool (see above, the efforts undertaken at the OECD, UNCTAD and WTO): "Investment facilitation is distinct from investment promotion, which is about promoting a location as an investment destination (e.g. through marketing and incentives) and is therefore often country-specific and competitive in nature. Investment facilitation is a horizontal policy instrument, applying to all sectors and industries" (UNCTAD, 2018, p. 157). The World Investment Report 2018 dedicated its annual theme to the role of industrial policies in national and international investment policies. The main approach of the report was to consider that the new industrial policy measures applied recently by numerous countries contribute to opening their markets to FDI. However, UNCTAD recognizes that industrial policies regarding FDI also comprise the regulations and constraints imposed on MNEs, such as minimum requirements, ownership limitations, and joint venture requirements (UNCTAD, 2018, p. 132). A darker side of industrial policy measure recently enforced by some countries is not sufficiently elaborated upon in UNCTAD viewpoints regarding the role of industrial policies in the evolution of FDI. Indeed, industrial policy induces the risk of market distortions, discrimination and unnecessarily restrictive measures (Clift and Woll,
2012, p. 312). This result may explain why recent measures implemented by some countries against some M\&A and investments may also affect the development of national and international investment policies in the future. The border between industrial policy measures promoting competition and economic development and economic patriotism measures is quite blurred in some instances: "In many cases it is no longer possible to draw a clear dividing line between national industrial policy in the sense of government influence on companies at home and protectionism in the sense of trade barriers to the outside world" (Wruuck, 2006, p. 5). For example, the reluctance of some countries to accept FDI from Chinese firms, through M\&A, may reflect the ambiguity of promoting inward $\mathrm{FDI}$, on the one side, and promoting national interests, on the other (Meunier, 2012; Tavares and Lehmann, 2017). This result is particularly the case when MNEs from emerging markets - in particular SOEs - invest in developed economies (Cuervo-Cazurra, 2018a). Any progress towards plurilateral or multilateral rules on investment may be jeopardized or at least hindered due to, among other aspects, measures implemented under the umbrella of industrial policies that generally receive the sympathy of populist nationalism fractions (Kobrin, 2017, p. 1).

\section{FDI policy and the digital economy}

The digital economy has led to new structures of the traditional landscape of MNEs' activities and has changed the competitive advantages of firms and locations (Alcácer et al., 2016, p. 499). The digital economy has an impact on foreign investment since it creates new conditions governing modes of entry, GVC operations, the comparative advantages of locations, etc. Regarding the motivation to invest abroad, according to the UNCTAD: "The digital economy also has implications for efficiency-seeking and resource-seeking investment by enabling new governance and coordination mechanisms in international production networks" (UNCTAD, 2017, p. 158). 
TABLE 5

\section{EMBEDDING DIGITAL DEVELOPMENT IN INVESTMENT POLICIES}

National

— "Assess the extent to which existing investment regulations are affected by digital operating models.

- Modernize investment regulations where needed, balancing investment promotion and facilitation with measures to mitigate risks associated with digital operating models".

International

— "Review the coverage and treatment of new digital industries in IIAs.

- Take into account the digital investment dimension of evolving international rules, such as those on e-commerce and services trade".

SOURCE: UNCTAD, 2017, p. 216.

The digital economy creates new opportunities and new challenges for the international investment policy community: "It remains, however, that an inherent tension exists between the potential benefits, both for firms and for economies, of the broadening adoption of digital technologies by MNEs. Governments are also facing mounting pressure to develop policy responses (especially in the realms of national security and privacy) that could run against the trend toward broader digital adaptation, possibly leading to digital fragmentation" (Gestrin and Staudt, 2018, p. 19).

Since the digital economy implies changes in MNEs' strategies and operations, it impacts the investment policy landscape (UNCTAD, 2017, p. 158). National and international investment policies need to be adapted to the new investment features implied by the digital economy (Table 5). At the national level, most regulations on investment have been designed for firms' physical activities. Some of these regulations are therefore obsolete. There are also risks that a distortion of competition may be created if the rules differ between digital and nondigital activities (UNCTAD, 2017, p. 185). At the international level, most international agreements and guidelines were adopted before the emergence of the digital economy (UNCTAD, 2017, p. 187). However, as underlined by Gestrin and Staudt: "Investment policies have not undergone any major changes in response to the digital economy" (Gestrin and Staudt, 2018, p. 15). The main changes observed so far are related to new developments undertaken by some countries willing to find responses to national security concerns (Pohl, 2019, p. 1). From 2017 to 2018 , nine of the ten largest economies modified their regulations on foreign M\&A for national security reasons, as did numerous small developing and developed countries (Pohl, 2019, p. 1). For example, Germany modified its regulations related to the screening of acquisitions that are operated by non-EU investors, while other countries (e.g. the United Kingdom, the Netherlands) are considering doing the same (Gestrin and Staudt, 2018, p. 16).

\section{Conclusions}

Some new developments have impacted the MNE strategies and therefore the features of FDI over the last few years, creating new challenges for the national and international policy framework on foreign investments. The main new development is the rise of emerging countries' MNEs, as well as the emergence of the digital economy (Eden, 2016, p. 3). On the one hand, developing and emerging countries are no longer concentrating their interests as host countries of FDI but are increasingly 
interested in facilitating and protecting their domestic MNEs' investments abroad (Sauvant, 2016, pp. 14-15). The efforts to harmonize the regulations and policies affecting international investment at the national and international levels are challenged by the increasing heterogeneity of investors (Eden, 2016, p. 11). Furthermore, the lengthy but steady trends toward the facilitation of foreign investment are put at risk by new industrial policy developments led by the rise of populist nationalism in some major trading partners (Kobrin, 2017, p. 1). Consequently, the increased transparency of the regulatory landscape, as well as the improvement of the current dispute settlement system, will be on the table of discussions on national and international policies impacting foreign investment in the near future. As stated by Buckley: "(...) transparent national policies with robust supranational monitoring are the best solution for world economic welfare" (Buckley, 2018, p. 184).

\section{Bibliographic references}

Alcácer, J., Cantwell, J., \& Piscitello, L. (2016). Internationalization in the information age: A new era for places, firms, and international business network? Journal of International Business Studies, 47, 499-512.

Alfaro, L. (2016). Gains from Foreign Direct Investment: Macro and Micro Approaches. The World Bank Economic Review, p. 1.

Buckley, P. J. (2017). The competitiveness of emerging country multinational enterprise: Does it derive from CSAs or FSAs? Competitiveness Review: An International Business Journal, 27(3), 208-216.

Buckley, P. J. (2018). Towards a theoretically-based global foreign direct investment policy regime. Journal of International Business Policy, 1, 184-207.

Clift, B., \& Woll, C. (2012). Economic patriotism: reinventing control over open markets. Journal of European Public Policy, 19(3), 307-323.

Cuervo-Cazurra, A. (2018). Host country concerns and policies toward state-owned MNEs. Columbia FDI Perspectives, (237), October 22, 2018.

Cuervo-Cazurra, A. (2018a). Thanks but no thanks: State-owned multinational from emerging markets and host-country policies. Journal of International Business Policy, 1, 128-156.

Dunning, J. H., \& Lundan, S. (2008). Multinational Enterprises and the Global Economy, Second Edition. Cheltenham, UK: Edward Elgar.
Eden, L. (2016). Multinationals and Foreign Investment Policies in a Digital World. E15 Initiative, International Centre for Trade and Sustainable Development (ICTSD) and World Economic Forum, Geneva. Available at http://www. e15initiative.org/, last accessed March 4, 2019.

European Commission (2018). Commission welcomes agreement on foreign investment screening framework. Brussels.

Feldman, M. (2018). International Investment Obligations and Industrial Policy: Evolution in Treaty Practice. RTA Exchange, International Centre for Trade and Sustainable Development (ICTSD) and Inter-American Development Bank (IDB), Geneva.

Gaukrodger, D. (2016). State-to-State dispute settlement and the interpretation of investment treaties. OECD Working Papers on International Investment, March 2016. OECD Publishing, Paris.

Gaukrodger, D. (2017). The balance between investor protection and the right to regulate in investment treaties: A scoping paper. OECD Working Papers on International Investment, February, 2017. OECD Publishing, Paris.

Gestrin, M. V., \& Staudt, J. (2018). The digital economy, multinational enterprises and international investment policy. OECD Publishing, Paris.

GPF (2019). Multilateral Agreement on Investment. Available at https://www.globalpolicy.org/social-and-economic-policy/ the-three-sisters-and-other-institutions/multilateral-agreement-on-investment.html, last accessed March 4, 2019.

Hamdani, K. (2018). Investment facilitation at the WTO is not investment redux. Columbia FDI Perspectives, (226), May 21.

Hees, F., \& Barreto da Rocha Paranhos, P. (2018). Investment facilitation: moving beyond investment promotion. Columbia FDI Perspectives, (228), June 18.

lammarino, S. (2018). FDI and regional development policy. Journal of International Business Policy, 1, 157-183.

Investment Policy Hub (2019). Introduction. Available at https://investmentpolicyhub.unctad.org/ipfsd, last accessed March 4, 2019.

Joseph, R. K. (2018). Investment facilitation: new dynamism at the WTO on investment. Columbia FDI Perspectives, (6.235), September 24.

Kobrin, S. (2017). The rise of nationalism, FDI and the multinational enterprise. Columbia FDI Perspectives, (212), November 6.

Meunier, S. (2012). Economic patriotism: Dealing with Chinese direct investment in the United States, Summary of a collective report. Columbia FDI Perspectives, (68), May 14.

Moran, T. H. (2018). CFIUS reforms must be reformed. Columbia FSI Perspectives, (231), July 30.

Novik, A., \& De Crombrugghe, A. (2018). Towards an Investment Framework for Investment Facilitation. OECD insight. 
OECD (2007). OECD Codes of Liberalisation: User's Guide 2008. OECD Publishing, Paris.

OECD (2009). Guidelines for Recipient Country Investment Policies Relating to National Security. Recommendation adopted by the OECD Council on May 25, 2009. Investment Division, Paris.

OECD (2011). OECD Reviews of Regional Innovation Regions and Innovation Policy, Paris.

OECD (2015). Policy Framework for Investment, 2015 Edition. OECD Publishing, Paris.

OECD (2017). Open and Orderly Capital Movements: Interventions from the 2016. OECD High-Level Seminar, Paris.

OECD (2018). OECD Code of Liberalisation of Capital Movements, Paris.

Pohl, J. (2018). Societal benefits and costs of International Investment Agreements: A critical review of aspects and available empirical evidence. OECD Working Papers on International Investment, January, 2018. OECD Publishing, Paris.

Pohl, J. (2019). Is International Investment threatening or under threat? Columbia FDI Perspectives, February 25.

Rodrik, D. (1995). Political economy of trade policy. Handbook of International Economics, 3, 1457-1494.

Sauvant, K. P. (2016). National FDI Policy Competition and the Changing International Investment Regime. In R. F. Oppong and W. Agyebeng, (Eds.), A Commitment to Law: Essays in Honour of Nana Dr. Samuel Kwadwo Boaten Asante. London: Wildy, Simmonds and Hill Publications.

Sauvant, K. P. (2016a). The Evolving International Investment Law and Policy Regime: Ways Forward. E15 Task Force on Investment Policy-Policy Options Paper. E15Initiative, International Centre for Trade and Sustainable Development (ICTSD) and World Economic Forum, Geneva.

Sauvant, K. P., \& Hamdani, K. (2015). An International Support Programme for Sustainable Investment Facilitation. E15 Initiative, International Centre for Trade and Sustainable Development (ICTSD) and World Economic Forum, Geneva.

Sauvant, K. P., \& Mann, H. (2017). Towards an Indicative List of FDI Sustainability Characteristics. E15 Initiative, International Centre for Trade and Sustainable Development (ICTSD) and World Economic Forum, Geneva.

Tavares-Lehmann, A., Toledano, P., Johnson, L., \& Sachs, L. (2016). Rethinking Investment Incentives: Trends and Policy Options. New York: Columbia University Press.

Tavares Lehmann, A., \& Lehmann, F. (2017). Outward direct investment by Chinese state-owned enterprises: Can host country policy act as a country-specific advantage? Competitiveness Review: An International Business Journal, 27(3), 231-252.
Tuerk, E., \& Rojid, F. (2012). Towards a New Generation of Investment Policies: UNCTAD's Investment Policy Framework for Sustainable Development, International Institute for Sustainable Development, Geneva.

UNCTAD (1999). Lessons from the MAI. UNCTAD Series on issues in international investment agreements, UNCTAD/ ITE/IIT/MISC., (22), New York and Geneva.

UNCTAD (2014). World Investment Report 2014, United Nations Publication, Geneva.

UNCTAD (2015). World Investment Report 2015, United Nations Publication, Geneva.

UNCTAD (2015a). Investment Policy Framework for Sustainable Development, Executive summary, Geneva.

UNCTAD (2016). World Investment Report 2016, United Nations Publication, Geneva.

UNCTAD (2017). World Investment Report 2017, United Nations Publication, Geneva.

UNCTAD (2017a). UNCTAD's Reform Package for International Investment Regime, New York and Geneva.

UNCTAD (2018). World Investment Report 2018, United Nations Publication, Geneva.

United Nations (2015). Transforming our World: The 2030 Agenda for Sustainable Development, A/RES/70/1, New York and Geneva.

Van Assche, A. (2018). From the editor: Steering a policy turn in international business- opportunities and challenges. Journal of International Business Policy, 1, 117-127.

Van Zanten, J. A., \& Van Tulder, R. (2018). Multinational enterprises and the Sustainable Development Goals: An institutional approach to corporate engagement. Journal of International Business Policy, 1, 208-233.

Wehrlé, F., \& Pohl, J. (2016). Investment Policies Related to National Security: A Survey of Country Practices. OECD Working Papers on International Investment, February 2016. OECD Publishing, Paris.

Wessner, Ch. W. (Ed.) (2009). Understanding Research, Science and Technology Parks: Global Best Practices. The National Economic Press, Washington.

WTO (2019). Investment facilitation: Relationship between trade and investment. Available at https://www.wto.org/ english/thewto_e/minist_e/mc11_e/briefing_notes_e/bfinvestfac_e.htm, last accessed March 4, 2019.

Wruuck, P. (2006). Economic Patriotism: New game in industrial policy? Deutsche Bank Research, Reports on European Integration EU Monitor 35, June 14.

Zang, J. (2018). Investment Facilitation: Making sense of concepts, discussions and processes. The International Institute for Sustainable Development, July 10. 


\section{Información Comercial Española Revista de Economía}

6 números anuales

Articulos originales sobre un amplio espectro de temas tratados desde una óptica económica, con especial referencia a sus aspectos internacionales

\section{Boletín Económico de Información Comercial Española}

\section{2 números anuales}

Artículos y documentos sobre economía española, comunitaria e internacional, con especial énfasis en temas sectoriales $y$ de comercio exterior

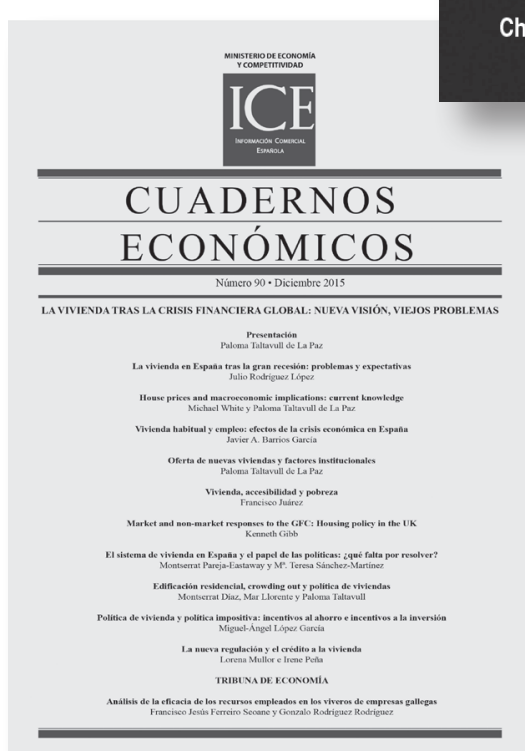

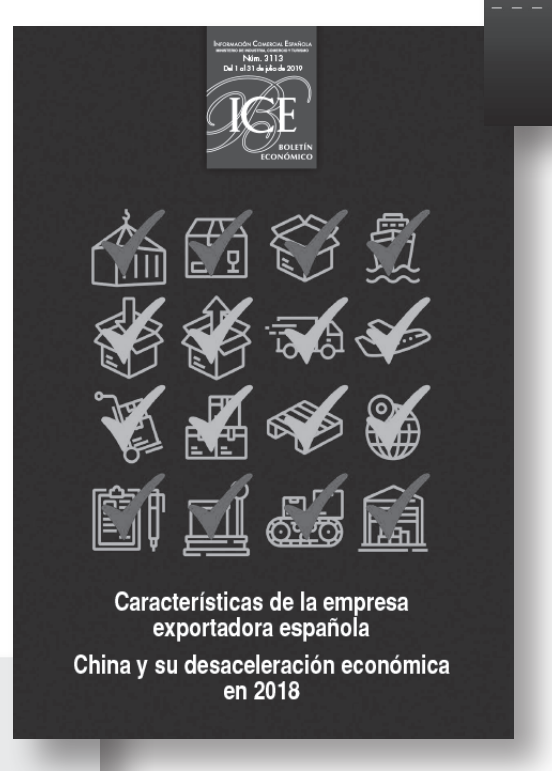

Espaîa ante el reto demográfico

Acceso libre

INTERNET

www.revistasice.com

\section{ICE}

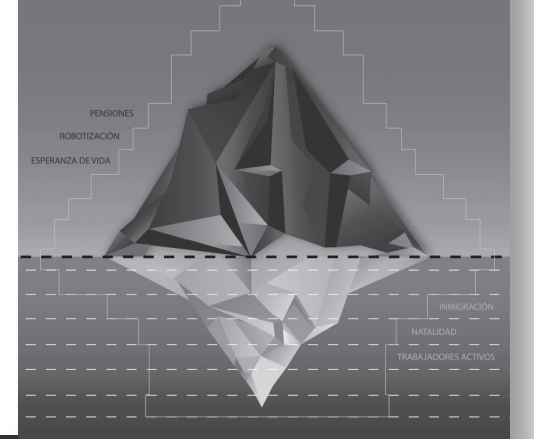

\section{Cuadernos Económicos de ICE}

\section{2 números anuales}

Artículos de economía teórica y aplicada y métodos cuantitativos, que contribuyen a la difusión y desarrollo de la investigación

Librería virtual y venta www.mincotur.es

Panamá, 1. 28046 Madrid

Telf. 913495129

CentroPublicaciones@mincotur.es 